\title{
CLONAL FORESTRY OF Araucaria angustifolia: PLANTS PRODUCED BY GRAFTING AND CUTTINGS CAN BE USED FOR WOOD PRODUCTION ${ }^{1}$
}

\author{
Ivar Wendling ${ }^{2}$, Carlos André Stuepp ${ }^{3 *}$, Delmar Santin ${ }^{4}$, Katia Christiana Zuffellato-Ribas ${ }^{5}$
}

\footnotetext{
${ }^{1}$ Received on 07.10.2015 accepted for publication on 16.03.2017.

${ }^{2}$ Embrapa Florestas, Colombo, PR - Brasil. E-mail: <ivar.wendling@embrapa.br>.

${ }^{3}$ Universidade Federal do Paraná, Programa de Pós-Graduação em Produção Vegetal, Curitiba, PR - Brasil. E-mail: <carlos.stuepp@ufpr.br>.

${ }^{4}$ Cambona Consultoria e Treinamento Agroindustrial Ltda., Santa Terezinha De Itaipu, PR - Brasil. E-mail: $<$ desantinflorestal@yahoo.com.br>.

${ }^{5}$ Universidade Federal do Paraná, Departamento de Botânica, Curitiba, PR - Brasil. E-mail: <kazu@ufpr.br>.

*Corresponding author.
}

\begin{abstract}
Araucaria angustifolia (Brazilian Pine or Araucaria) is a potential native species to Brazilian forestry. However, a number of challenges and technical restraints still persist, making difficult its expansion as a species for forest plantations, among which the lack of cloning technologies evaluation in field conditions. So the present study aimed to evaluate the potential use of Araucaria plants produced by cuttings and grafting for wood production in comparison to those produced by seeds, by assessing field vigor and establishing a form factor for plantations with equivalent age. Plants from cuttings and seeds were planted in a $3 \times 3 \mathrm{~m}$ spacing, being part of the last intended to be rootstocks for grafting. The experiment was conducted in a completely randomized design with three treatments and plots of a plant (one tree plot). Plants from cuttings had higher growth in diameter at breast height $(7.4 \pm 2.41 \mathrm{~cm})$ and total height $(4.2 \pm 1.08 \mathrm{~m})$ at 74 months after planting, followed by grafted plants and from seeds, with similar results. We conclude that cuttings and grafting are potential techniques for Araucaria plants formation for wood production, and, in particular, grafting is recommended by the easiness of in its application, besides the fact that it can be used for seed orchards formation and presents volumetric increase and form factor similar to seedlings.
\end{abstract}

Keywords: Vegetative propagation methods; Volumetric increase; Growth habit.

\section{SILVICULTURA CLONAL DE Araucaria angustifolia: MUDAS PRODUZIDAS POR ENXERTIA E ESTAQUIA PODEM SER USADAS PARA PRODUÇÃO DE \\ $M A D E I R A$}

\begin{abstract}
RESUMO - Araucaria angustifolia (pinheiro-brasileiro ou araucária) é uma espécie nativa potencial para a silvicultura brasileira. No entanto, uma série de desafios e limitações técnicas ainda persistem, dificultando sua expansão como espécie para plantios florestais, dentre os quais se destaca a falta de avaliação de tecnologias de clonagem de materiais genéticos em condições de campo. O presente estudo objetivou avaliar a potencialidade da utilização de mudas de araucária produzidas por estaquia e enxertia para produção madeireira em comparação às produzidas por sementes, por meio da avaliação do vigor vegetativo a campo e assim estabelecer um fator de forma para plantios com idade equivalente. Mudas provenientes de estaquia e de sementes foram plantadas a campo em espaçamento $3 \times 3 \mathrm{~m}$, sendo parte das últimas destinadas a servirem de porta-enxertos para enxertia. O experimento foi conduzido num delineamento inteiramente casualizado, com três tratamentos e parcelas de uma planta (one tree plot). Plantas provenientes de estaquia apresentaram maior crescimento em diâmetro a altura do peito $(7,4 \mathrm{~cm})$ e altura total $(4,2 \mathrm{~m})$ aos 74 meses após o plantio, seguidas das mudas de enxertia e sementes, com resultados similares. Conclui-se que a estaquia e a enxertia são técnicas potenciais para a produção de mudas de araucária para fins madeireiros, sendo, de modo especial, a enxertia
\end{abstract}


recomendada pela facilidade de execução, além do fato de poder ser utilizada para formação de pomares para produção de sementes e apresentar incremento volumétrico e fator de forma similar a mudas produzidas por sementes.

Palavras-chave: Métodos de propagação vegetativa; Incremento volumétrico; Hábito de crescimento.

\section{INTRODUCTION}

Popularly known as Araucaria or Brazilian Pine, Araucaria angustifolia (Bertol.) Kuntze occurs naturally in Southern Brazil, especially in Eastern and Central part of Brazilian highlands (Carvalho, 2003). In the 1940 and 1950 decades its occurrence areas suffered a considerable reduction due to its wood exploitation, much appreciated because of attractive features to the wood industry, currently remaining less than $2 \%$ of its original formation (Delucis et al., 2013). At that time, the species was responsible for a huge economic and social development in the regions where it occurs.

The natural propagation of Araucaria is by seeds. However, this method presents a number of disadvantages, such as the low longevity of seeds, creating difficulties in storage (Moreira-Souza and Cardoso, 2002) or yet, the uncertainty of the sex until maturity and the genetic variability of the produced seedlings. Araucaria seeds are physiologically classified as recalcitrant (Corbineau et al., 1997). The seeds have as peculiarity a high sensitivity to desiccation and at the same time, an intolerance to storage at low temperatures, complicating their storage over extended periods (Amarante et al., 2007).

The use of cuttings in Araucaria plants production presents itself as an alternative for overcoming these deficiencies, enabling the production of plants with quality and uniformity identical to stock plants, and especially during the whole year, regardless of seed production (Wendling et al., 2009; Reis et al., 2011; Griffin, 2014; Wendling et al., 2016). Nevertheless, the few attempts related to vegetative propagation by cuttings of this species have not shown the aimed efficiency, with results that did not exceed 25\% (Iritani and Soares, 1983) to $30 \%$ of rooting (Wendling and Brondani, 2015), even with the use of advanced propagation techniques via mini-cuttings (Pires et al., 2013). In addition, there are no studies about the assessment of the behavior of plants produced by cuttings in the field.

Grafting has been widely applied in forestry, primarily for the formation of seed orchards (Zhang

Revista Árvore. 2017;41(1):e410117 et al., 2010; Asaah et al., 2011). Its application for Araucaria angustifolia is recommended by the use of orthotropic branches (Kageyama and Ferreira, 1975) in order to achieve plants with proper growth vigor. Despite the reasonable dissemination of grafting technique in this species (Wendling, 2011; Zanette et al., 2011), at this point, there are no references of its directly use in the field or for wood purposes.

From the forestry point of view, volumetric models for estimation of volume based on easy measurement independent variables have been frequently used for forest species. However, they become instruments of great complexity, and depend on a deeper analysis of the individual evaluated trees characteristics (Cabacinha et al., 2013). Thus, a rapid estimate of individual volume can be obtained through the determination of a form factor, in which the imperfections of cylinder to real tree volume are sought to be corrected, providing a reliable and directly-dependent estimate of the species, the spacing and the production site (Miguel et al., 2010).

Considering the exposed, this study aimed to evaluate the survival and field growth vigor of Araucaria plants produced by cuttings and grafting, comparing them with those produced by the traditional method via seeds, as well as to establish a form factor for plantations with equivalent age.

\section{MATERIALAND METHODS}

Characterization of the experimental area. The experiment was conducted from May 2008 to June 2014 at the Experimental Station of Embrapa Florestas, Colombo-PR (25'20' S and 49 $14^{\prime}$ W, $950 \mathrm{~m}$ ). According to Köppen classification, region climate is temperate, Cfb type, with coldest month temperature between 3 and $18^{\circ} \mathrm{C}$, always humid, with well distributed rainfall throughout the year and mean temperature of hottest month less than $22^{\circ} \mathrm{C}$. Regarding chemical properties, the soil presented low fertility. Regarding chemical properties, the soil presented low fertility, the $0-30 \mathrm{~cm}$ layer of soil contained $\mathrm{pH}$ of $4.30 ; \mathrm{Ca}^{2+}, \mathrm{Mg}^{2+}, \mathrm{Al}^{3+}, \mathrm{H}++\mathrm{Al} 3+$ and $\mathrm{CTC}_{\mathrm{pH} 7.0}$, respectively, of 2.60, 1.20, 1.70, $10.50 \mathrm{e}$ 
$14.37 \mathrm{cmolc} \mathrm{dm}^{-3} ; \mathrm{P}$ and $\mathrm{K}$, respectively, of 5.00 and $27.37 \mathrm{mg} \mathrm{dm}^{-3}$; C with $27.6 \mathrm{~g} \mathrm{dm}^{-3}$ and base saturation, saturation by $\mathrm{Al}^{3+}$ and clay content, respectively, of 27,31 and $25 \%$.

Plants production. Cuttings were produced with orthotropic shoots, derived from plants established in a field clonal garden $(0.5 \mathrm{~m} \times 0.5 \mathrm{~m}$ spacing $)$, previously produced by cuttings with shoots from 30-years-old trees, subject to coppicing for basal orthotropic shoots obtainment, as detailed in Wendling and Brondani (2015). Cuttings were prepared with $15-20 \mathrm{~cm}$ long and 5-10 mm diameter, with removal of $1 / 3$ of the basal needles, aiming to facilitate planting. They were planted in small tubes of polypropylene with $280 \mathrm{~cm}^{3}$ of capacity, filled with mean granulometry vermiculite and carbonized rice husk $(1: 1, \mathrm{v} / \mathrm{v})$.

The tubes were put in a climatized greenhouse during 120 days with intermittent fogging (temperature of $25^{\circ} \mathrm{C} \pm 5^{\circ} \mathrm{C}$ and relative humidity higher than $80 \%$ ). Later, the cuttings went through the process of acclimatization in a shade house (netted shade of 50\%) during 30 days, and rustication in full sun area during 30 days more.

The seedlings were produced from seeds derived from the city of Faxinal do Céu-PR $\left(24^{\circ} 00^{\prime} \mathrm{S}\right.$ and $51^{\circ}$ $\left.19^{\prime} \mathrm{O}\right)$. They were produced in plastic tubes with 280 $\mathrm{cm}^{3}$ of capacity, filled with commercial substrate of pine bark and coconut fiber base, which were placed in a glasshouse $\left(20 \pm 18{ }^{\circ} \mathrm{C}, 20-50\right.$ to $90 \%$ humidity and irrigation by sprinkling [ $1 \mathrm{~min}, 3$ times per day]). After, they went through the rustication process and pre-planting selection for the treatments homogenization.

Planting in the field. Planting in the field was held in May 2008, in circular pits of $75 \mathrm{~cm}$ deep and $25 \mathrm{~cm}$ in diameter, made with a machine for soil boring drill holes coupled with tractor strength, in a $3 \mathrm{~m} \mathrm{x}$ $3 \mathrm{~m}$ spacing. The fertilizing with $200 \mathrm{~g}$ of NPK (4-148 ) per pit was carried out, incorporating it along with the soil removed from the pits. At the planting moment, cuttings aged six months, and the seedlings, four months.

Grafting in the field. In October 2009 grafting directly in the field was carried out with the use of rootstocks from seedlings planted in May 2008. The grafts were from epicormic shoots produced in clonal garden, similarly to the shoots used for cuttings production.
The grafting was held by cleft grafting in the top of the rootstock method (Wendling, 2011) at a height of 20 to $30 \mathrm{~cm}$ from the ground, using ribbon to fix the graft to the rootstock. The grafts were covered by transparent plastic bags to form a wet chamber to reduce the loss of humidity. Then, a "kraft" type brown paper package was put on the plastic bag for protection against luminosity excess. The ribbons were kept for three months or less, in case there was the occurrence of stems thickening. The plastic bags were opened at the beginning of grafts shooting, being removed 10 days after its opening, along with the paper packages.

Area management and evaluations. Prior to plantation, total area mechanical grubbing was carried out in the experiment, followed by leaf-cutting ants control. The post-planting treatments consisted in mechanical grubbing held every six months, and control of leaf-cutting ants whenever necessary. In September 2013 a pruning was held, removing $1 / 3$ of crown area of each plant.

During the experiment the plants (cuttings, grafting and seedlings) survival at 24 months after field planting were evaluated, coinciding with six months after grafting (DAG) for grafts, in addition to total height (at 48, 66 and 74 months), diameter at breast height (DBH) and occurrence of male and female reproductive organs in plants at 66 and 74 months. Based on DBH and height data evaluated at 74 months, the respective form factors for each type of material (grafts, cuttings and seedlings) were calculated. Subsequently, based on these form factors, mean volume per plant and mean annual increase per hectare were calculated at 66 and 74 months.

For determination of form factor, rigorous scaling was carried out. In order to do this, grafting, cuttings and seedling plants were selected based on DBH values. The minimum DBH class adopted was of $2 \mathrm{~cm}$, and the range of the classes varied according to plants origin, being $2 \mathrm{~cm}$ for grafts and seedlings and $3 \mathrm{~cm}$ for cuttings. Based on center diameter of each class, trees to be scaled in field were determined, two by class (Tabela 1).

The calculation of volume was carried out by Smalian's formula, by measuring the diameter of the base (at $0.30 \mathrm{~m}$ above ground), center (midpoint of each tree total height) and apex (just below last branches insertion of), i.e., $\mathrm{D}_{1}, \mathrm{D}_{2}, \mathrm{D}_{3}$, limited by total height

Revista Árvore. 2017;41(1):e410117 
Table 1 - Plantation in different diametric classes and treatments adopted.

Tabela 1 - Frequência de árvores cubadas para o povoamento de Araucaria angustifolia nas diferentes classes diamétricas adotadas e tratamentos.

\begin{tabular}{lccc}
\hline Origin & Class & $\begin{array}{c}\text { Class interval } \\
(\mathrm{cm})\end{array}$ & $\begin{array}{c}\text { Class Center } \\
(\mathrm{cm})\end{array}$ \\
\hline Grafting & 1 & $2.0-4.0$ & 3.1 \\
& 2 & $4.1-6.0$ & 5.1 \\
& 3 & $6.1-8.1$ & 7.1 \\
\hline Cuttings & 1 & $3.0-6.0$ & 4.6 \\
& 2 & $6.1-9.0$ & 7.6 \\
& 3 & $9.1-12.1$ & 10.6 \\
\hline Seeds & 1 & $2.0-4.0$ & 3.1 \\
& 2 & $4.1-6.0$ & 5.1 \\
& 3 & $6.1-8.1$ & 7.1 \\
\hline
\end{tabular}

of measured trees. Later, total volume was calculated through sum of each section volumes, according to equation:

$T v=\mathrm{L} \cdot \frac{\left(\mathrm{g}_{1}+\mathrm{g}_{2}\right)}{2}+\mathrm{L} \cdot \frac{\left(\mathrm{g}_{2}+\mathrm{g}_{3}\right)}{2}$, in which: Tv $=$ Total volume; $g_{1}, g_{2}$ and $g_{3}=$ Cross-sectional area of the extremities 1, 2 and 3, respectively; $\mathrm{L}=$ Height of section.

The calculation of form factor (ff) was carried out, defined by ratio between real volume, obtained by rigorous scaling and cylinder volume, as shown in equation:

$f f=\frac{V \text { real }}{V c y l}$, in which: $\mathrm{V}_{\text {real }}=$ real volume (rigorous scaling volume) and $\mathrm{V}_{\text {cyl }}=$ cylinder volume.

Experimental design and statistical analysis. Randomized blocks were used for experimental design, with one tree plot parcel, consisting of three treatments (grafting, cuttings and seedlings plants), with 7 to 30 repetitions per treatment (which vary depending on the availability of material). For statistical analysis, variances of treatments were evaluated regarding homogeneity by Bartlett test $(p<0.05)$, and variables with significant differences by that test had their means compared by Tukey test at $5 \%$ of probability.

\section{RESULTS}

After 24 months of field planting of all propagation treatments, plants from cuttings have shown greater survival (97.6\%) compared to those from seeds $(75.9 \%)$ and grafts $(76.0 \%)$ (Figure 1).

Cuttings plants presented significantly higher total height at 48, 66 and 74 months after planting, when compared to plants from seeds and grafting, which showed results similar between each other (Figure $2 a$ ). Similarly to total height, plants from cuttings presented higher diameter breast height (DBH) at $66(4.8 \mathrm{~cm})$ and $74(7.4 \mathrm{~cm})$ months of age. Plants from grafting and seeds showed mean DBH of $5.5 \mathrm{~cm}$ at 74 months (Figure 2b).

Regarding form factor, variation was verified in accordance to propagation technique from which the plants derived. Cuttings plants showed greater conicity (0.45) compared to plants from seeds and grafting (0.52) (Table 2).

Values for mean volume per plant and annual mean increase were higher for cuttings on both evaluations. Mean volume per plant from cuttings was higher compared to others, around 4 and 2.2 times to the evaluation at 66 and 74 months, respectively (Figure 3a). On the other hand, for annual mean increase, cuttings plants exceeded the grafting ones in 3.4 times, and 3.5 times the seed plants at 66 months of age, and 2.2 and 2.0 times at 74 months, respectively (Figure $3 \mathrm{~b}$ ).

Regarding the emission of male and female strobiles, until 74 months after planting, its emission was not observed, regardless of plants origin.

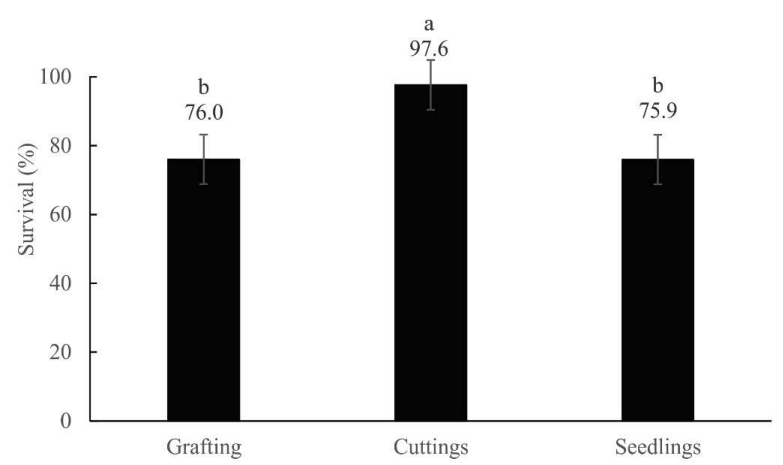

Figure 1 - Survival of Araucaria angustifolia plants at 24 months (cuttings and seeds) and 180 days after grafting (grafts). Means followed by the same letter do not differ among themselves by Tukey test at $5 \%$ probability. The bars indicate standard error of the mean $(\mathrm{n}=20)$.

Figura 1-Sobrevivência de plantas de Araucaria angustifolia aos 24 meses (estacas e sementes) e enxertos 180 dias após enxertia. Médias seguidas por mesma letra não diferem entre si pelo teste de Tukey a $5 \%$ de probabilidade. As barras indicam o erro padrão da média $(n=20)$. 


\section{DISCUSSION}

The greatest and similar survival rates of plants derived from cuttings and grafting in relation to those from seeds, respectively, indicate a good potential of initial adaptation of those plants to planting conditions (Figure 1). Some species, when propagated by cuttings, may develop a more fasciculated root system, initially increasing thin roots volume, responsible for a large

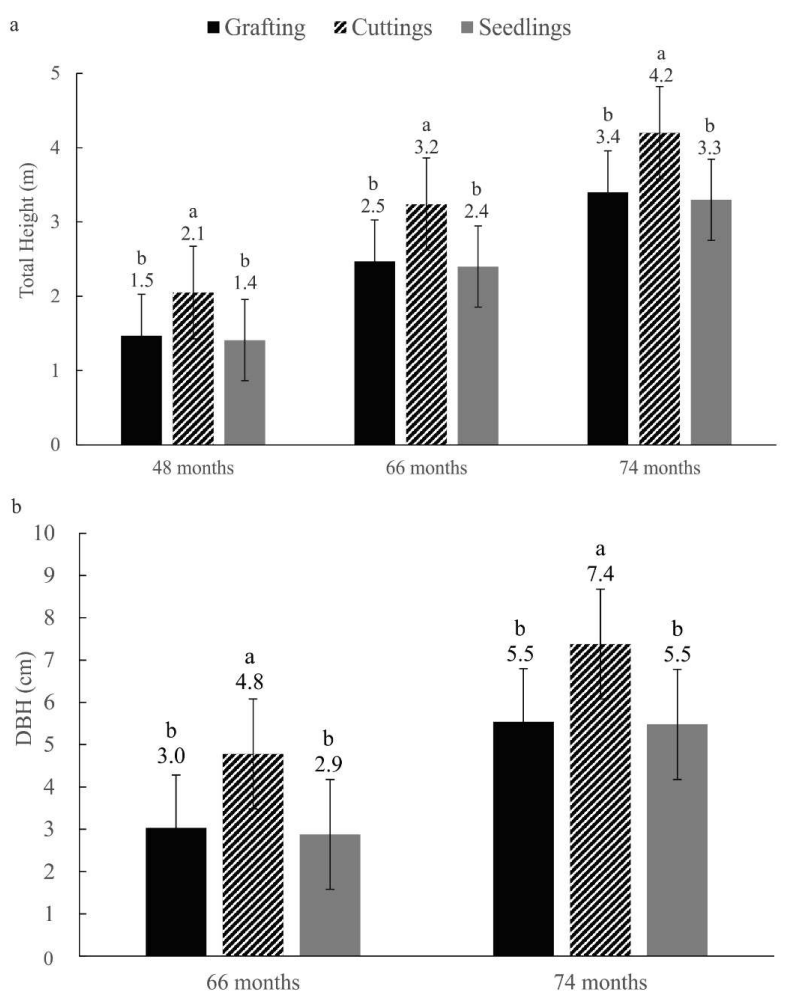

Figure 2 - Mean total height at 48, 66 and 74 months after planting (a) and diameter at breast height (DBH) at 66 and 74 months after planting (b) in function of propagation method used in Araucaria angustifolia planting. Means followed by same letter do not differ among themselves by Tukey test at $5 \%$ probability. The bars indicate standard error of the mean $(\mathrm{n}=20)$

Figura 2-Altura total média aos 48, 66 e 74 meses após o plantio (a) e diâmetro a altura do peito (DAP) aos 66 e 74 meses após o plantio (b) em função do método de propagação utilizado em plantio de Araucaria angustifolia. Médias seguidas por mesma letra não diferem entre si pelo teste de Tukey a $5 \%$ de probabilidade. As barras indicam o erro padrão da média $(n=20)$. part of nutrients and water absorption (Gonçalves and Mello, 2005). This hypothesis was also defended by Santin et al. (2015) where productivity of Ilex paraguariensis plants, propagated by mini-cuttings, proved to be higher than the one originated from seeds. As it is not rare for vegetative propagation to change root morphological aspects of plants (Wendling, 2004), the hypothesis that Araucaria angustifolia propagated by cuttings have developed a more root system efficient regarding water and nutrients absorption is not discarded, favoring a greater survival of such species.

The good survival and growth rates of Araucaria grafted plants (Figure 1) demonstrate the feasibility of applying this technique directly in the field. Grafting has been widely employed in forest species breeding programs (Zhang et al., 2010; Asaah et al., 2011), frequently aiming to obtain reduced-sized plants, flowering precocity and maintenance of stock plants characteristics (Mencuccini et al., 2004). There are no records of the use of Araucaria grafting directly in the field, and studies carried out in nursery show survival rates from 0 to $100 \%$ using different cleft grafting and budding techniques (Gurgel and Gurgel Filho, 1967; Kageyama and Ferreira, 1975; Zanette et al., 2011), which vary depending on time, methodologies and growth habit of used material.

Based on a vigor reduction assumption in grafted plants, the use of grafting technique for Araucaria angustifolia was expected not to be viable for formation of clonal plantings for wood purposes. However, the strategy adopted in this study related to use of juvenile tissues, such as grafts derived from basal shoots, allows the application of grafting technique with new horizons, maintaining vigor associated with juvenility of vegetative propagules (Mencuccini et al., 2007; Bond et al., 2007; Hamid and Mencuccini, 2008; Wendling et al., 2014). The similar performance of grafting plants in relation to seedling (Figs. 1, 2 and 3), combined with the absence of male and female strobiles emission until the last evaluation (74 months), confirm the possibility of applying this propagation technique aiming at wood production, having no evidence of vigor loss and precocity in the production of reproductive structures.

In studies performed with Araucaria cunnighamii grafting, Nikles (1961) verified that three years after grafting, the first male strobiles arose, being the precocity 
Table 2 - Estimate of real mean volume, mean cylinder volume and mean form factor of Araucaria angustifolia plants derived from grafting, cuttings and seeds per diametric class at 74 months.

Tabela 2 - Estimativa do volume médio real, volume médio do cilindro e fator de forma médio de plantas de Araucaria angustifolia provenientes de enxertia, estaquia e de sementes por classe diamétrica aos 74 meses.

\begin{tabular}{|c|c|c|c|c|c|}
\hline $\begin{array}{l}\text { Propagation } \\
\text { method }\end{array}$ & $\begin{array}{l}\text { Class Center } \\
(\mathrm{cm})\end{array}$ & $\begin{array}{l}\text { Real Volume } \\
\qquad\left(\mathrm{m}^{3}\right)\end{array}$ & $\begin{array}{l}\text { Cylinder volume } \\
\text { (m3) }\end{array}$ & $\begin{array}{l}\text { Mean Form } \\
\text { Factor }\end{array}$ & *Mean standard error \\
\hline \multirow{3}{*}{ Grafting } & 3.1 & 0.003 & 0.004 & 0.61 & 0.047 \\
\hline & 5.1 & 0.014 & 0.029 & 0.49 & 0.002 \\
\hline & 5.1 & 0.020 & 0.042 & 0.47 & 0.038 \\
\hline \multirow[t]{2}{*}{ Mean } & & 0.012 & 0.025 & 0.52 & 0.029 \\
\hline & 7.1 & 0.020 & 0.047 & 0.42 & 0.017 \\
\hline \multirow[t]{2}{*}{ Cuttings } & 7.1 & 0.043 & 0.096 & 0.45 & 0.087 \\
\hline & 4.6 & 0.058 & 0.111 & 0.52 & 0.040 \\
\hline Mean & & 0.040 & 0.085 & 0.46 & 0.048 \\
\hline \multirow{3}{*}{ Seed } & 3.1 & 0.004 & 0.008 & 0.52 & 0.111 \\
\hline & 3.1 & 0.010 & 0.018 & 0.57 & 0.037 \\
\hline & 5.1 & 0.017 & 0.035 & 0.47 & 0.035 \\
\hline Mean & & 0.010 & 0.020 & 0.52 & 0.061 \\
\hline
\end{tabular}

* Mean standard error for form factor $(n=2)$.

of grafts from plagiotropic branches greater in relation to orthotropic branches. For Araucaria angustifolia, induction of flowering of male and female grafted plants of reduced size may occur at 4 and 6.5 years old, respectively, when propagules from adult part of stock plant is used (Wendling, 2011, 2015).

Similar results of height and diameter growth among plants from seeds and grafting (Figure $2 \mathrm{a}$ and $\mathrm{b}$ ), in addition to advantages associated with vegetative propagation (Xavier et al., 2013) and, mostly, the simplicity of grafting application, confirm its indication for clones production aiming clonal plantations for wood. In addition, grafting is easily carried out in field, without needing special structures, as in the case of cuttings (Dias et al., 2012). Furthermore, Araucaria angustifolia grafting directly in the field may represent an option for seeds orchards formation aiming nuts production, since it is a dioecious species (Carvalho, 2003) and, consequently, selection of stock plants sex can be held at grafting time rather than only after their maturation, which occurs around 12 to 15 years.

The initial growth of Araucaria is slow regardless of site, although from 36 months, in suitable sites, the species may present mean cumulative growth in height of up to $1.0 \mathrm{~m}$ year-1 (Carvalho, 2003). Similarly, Machado et al. (2014) verified mean cumulative growth in height of $1.1 \mathrm{~m}$ year ${ }^{-1}$ for planting aged 3 years. In the present study, we observed that growth in height remained constant until 74 months, without evidence of growth spurts from third year after planting, regardless propagation method
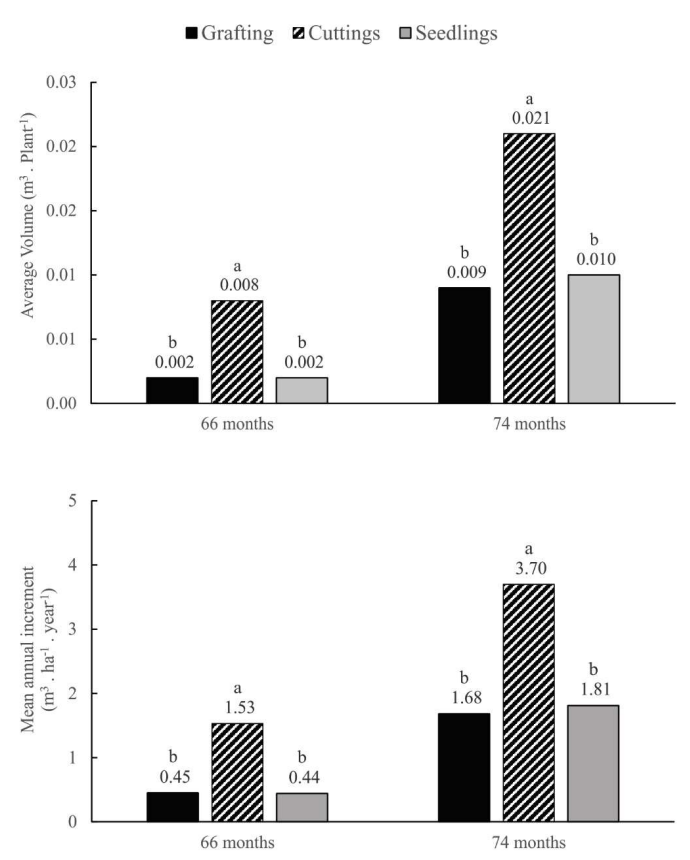

Figure 3 - Cumulative mean volume (a) and mean annual increase (b) at 66 and 74 months after planting in Araucaria angustifolia trees from different propagation methods. Means followed by same letter do not differ among themselves by Tukey test at $5 \%$ probability.

Figura 3 - Volume médio acumulado (a) e incremento médio anual (b) aos 66 e 74 meses após o plantio em árvores de Araucaria angustifolia provenientes de diferentes métodos de propagação. Médias seguidas por mesma letra não diferem entre si pelo teste de Tukey a 5\% de probabilidade. 
(Figure 2a). Mean cumulative growth in height of cuttings plants ranged from $0.51 \mathrm{~m}$ year ${ }^{-1}$ at 48 months and 0.68 m year ${ }^{-1}$ at 74 months, surpassing the mean cumulative growth of plants derived from seeds $\left(0.54 \mathrm{~m}\right.$ year $\left.^{-1}\right)$ and grafting $\left(0.55 \mathrm{~m} \mathrm{year}^{-1}\right)$ at 74 months (Figure $\left.2 \mathrm{a}\right)$.

The fact that higher mean annual increase in height, of $0.68 \mathrm{~m}$ year ${ }^{-1}$, obtained in plants from cuttings at 74 months (Figure 2a) be below 1.0 m year $^{-1}$ (Carvalho, 2003), and of $1.1 \mathrm{~m} \mathrm{year}^{-1}$ (Machado et al., 2014), is possibly related to low site fertility of experimental area. This hypothesis is supported by the fact that Araucaria is a demanding species in relation to soil conditions, especially regarding depth (Puchalski et al., 2006) and nutrient availability (Golfari, 1971, Schneider et al.; 1992, Carvalho, 2003). In a study with the species, Schneider et al. (1992) verified dominant height at 70 months of 2.7 and $5.5 \mathrm{~m}$, respectively, for the worst and best site in the same region, confirming the significant influence of soil properties on the planting efficiency. Thus, the low fertility of local site, mainly by low availability of $\mathrm{P}$ and $\mathrm{K}$, may have contributed to a growth in height lower than the one recorded for this species with approximate ages.

The growth behavior in DBH was similar to mean total height (Figure 2b). It is worth highlighting the good results obtained for plants originated from field grafting as well, similar to those recorded for seedlings. Regarding Araucaria plants aged between 40 and 60 years, Zanon et al. (2009) verified mean cumulative growth in DBH of $0.24 \mathrm{~cm}_{\text {year }}{ }^{-1}$. Such results are lower than those verified in this study, and prove the theory of high vigor associated with juvenile phase of this species presented by Machado et al. (2014). These authors observed a mean cumulative growth in diameter at $10 \mathrm{~cm}$ from the ground $\left(D_{10}\right)$ of $1.97 \mathrm{~cm}_{\text {year }}{ }^{-1}$ for a three years plantation, noting the conic format of its trunk in juvenile phase, which enables higher results of diameter in plant base $\left(\mathrm{D}_{10}\right)$ in relation to $1.30 \mathrm{~m}$ diameter $(\mathrm{DBH})$ on same evaluation.

Comparing individual volume and IMA in two periods of evaluation (66 and 74 months), it is clear that plantation is in linear positive growth (Figs. 3a and 3b). Increase in wood productivity verified over the last eight months (from 66 to 74 months) surpassed IMA. These results suggest a common effect in tree species during first years of life, which have their growth very dependent on apical meristem (Mencuccini et al., 2007).
IMA values verified for Araucaria in the present study are close to those found for some coniferous species. In a Pinus taeda provenance tests planted with $6.25 \mathrm{~m}^{2}$ plant $^{-1}$, annual increase verified at 72 months ranged between 5.3 and $26.6 \mathrm{~m}^{3} \mathrm{ha}^{-1}$ year $^{-1}$ in south Brazil (Shimizu etal., 1981). Similarly, for different spacings in plantings of the same species, variation in mean annual increase was $7.5 \mathrm{~m}^{3} \mathrm{ha}^{-1}$ year $^{-1}\left(7.5 \mathrm{~m}^{2}\right)$ and 24.8 $\mathrm{m}^{3} \mathrm{ha}^{-1}$ year $^{-1}\left(4.0 \mathrm{~m}^{2}\right)$ (Lima et al., 2013).

Form factor variation showed direct influence of propagation techniques that originated planting (Table 2). This variable can be influenced by several factors: age, soil and climate characteristics (Schneider et al., 1996) and, as the age of plantation increases, tendency is that trunk conicity becomes smaller and, consequently, form factor increases. For adult Araucaria trees in their native environment with DBH between 50 and $160 \mathrm{~cm}$,

Mattos et al. (2010) verified form factor ranging from 0.40 to 0.86 . In some cases, even plants with $\mathrm{DBH}$ higher than $150 \mathrm{~cm}$ showed form factor below 0.60 , demonstrating the wide range of this species on that characteristic.

Combined with high quality of its wood (Carvalho, 2003), Araucaria angustifolia is a good alternative for forestry purposes, especially with the use of improved materials.

It can also, with the use of grafting methodology, generate a new perspective regarding seeds production for food purposes. Despite the initial development below expectations, probably related to edaphic conditions, this tends to evolve with best plants adaptation to environment, or even with use of areas with better fertility conditions.

\section{CONCLUSION}

Cuttings and grafting are potential techniques for Araucaria plants production for wood purposes. Grafting in particular, is recommended by its simple application, besides the fact it can be used for seed orchards formation, and present volumetric increase and form factor similar to seedlings.

\section{ACKNOWLEDGMENTS}

We would like to thank SIMEPAR for making available the data regarding temperature and humidity for Colombo, PR. 


\section{REFERENCES}

Almeida FD, Xavier A, Dias JMM, Paiva HN. Eficiência das auxinas (AIB e ANA) no enraizamento de miniestacas de clones de Eucalyptus cloeziana F. Muell. Revista Árvore. 2007;31(3):455-63.

Asaah E, Tchoundjeu Z, Ngahane W, Tsobeng A, Kouodiekong L, Jamnadass R et al. Allanblackia floribunda: a new oil tree crop for Africa: amenability to grafting. New Forests. 2011;41(3):389-98.

Amarante C, Talamini CV, Mota S, Megguer CA, Ide GM. "Conservação pós-colheita de pinhões [sementes de Araucaria angustifolia (Bertoloni) Otto Kuntze] armazenados em diferentes temperaturas". Ciência Rural. 2007;37(2):346-51.

Bond BJ, Czarnomski NM, Cooper C, Day ME, Greenwood MS. Developmental decline in height growth in Douglasfir. Tree Physiology.

2007;27:441-53.

Cabacinha CD, Scolforo JRS, Thiersch CR, Sales NLP, Carvalho, LR. Uma nova abordagem para o método geométrico usando o índice da parábola. Ciência Florestal. 2013;23(1):261-71.

Carvalho PER. Espécies arbóreas brasileiras. Brasília, DF: Embrapa Informação Tecnológica; Colombo: Embrapa Florestas; 2003.

Corbineau F, Salmen Espindola L, Vinel D. Cellular and metabolic events associated with dehydration of recalcitrant Araucaria angustifolia embryos. In: Ellis RH, Black M, Murdoch AJ, Hong TD, editors. Basic and applied aspects of seed biology. Reding: 1995; Dordrecht: Kluwer Academic; 1997. p.715-21.

Delucis RDA, Gatto DA, Stangerlin DM, Beltrame R, Trevisan R. Qualificação da madeira de três espécies de coníferas oriundas de reflorestamentos jovens. Scientia Forestalis. 2013;41(100):477-84.

Dias PC, de Oliveira LS, Xavier A, Wendling I. Estaquia e miniestaquia de espécies florestais lenhosas do Brasil. Pesquisa Florestal Brasileira. 2012;32(72):453-62.

\section{Revista Árvore. 2017;41(1):e410117}

Fowler JP, Bianchetti A, Zanon A. Conservação de sementes de pinheiro do Paraná sob diferentes condições de ambientes e embalagens. Colombo: Embrapa Florestas; 1998. (Comunicado técnico, 34).

Golfari L. Coníferas aptas para o reflorestamento nos Estados do Paraná, Santa Catarina e Rio Grande do Sul. Boletim Técnico IBDF. 1971(1):171 .

Gonçalves JLM, Mello SLM. O sistema radicular das árvores. In: Gonçalves JLM, Benedetti V. Nutrição e fertilização florestal. Piracicaba: IPEF; 2005. p.219-67.

Griffin AR. Clones or improved seedlings of Eucalyptus? Not a simple Choice. International Forestry Review. 2014;16(2):216-24.

Gurgel JTA, Gurgel-Filho CA. Métodos de enxertia para o pinheiro brasileiro Araucaria angustifolia (Bertol.) O. Ktze., visando à formação de pomares de sementes. Silvicultura.1967;6:153-5.

Hamid HA, Mencuccini M. Age and sex related changes in physical characteristics and chemical composition of Acer pseudoplatanus and Fraxinus excelsior trees. Tree Physiology. 2008;29:27-38.

Iritani C, Soares RV. Indução do enraizamento de estacas de Araucaria angustifolia através da aplicação de reguladores de crescimento. Silvicultura. 1983;8(28):313-7.

Kageyama PY, Ferreira M. Propagação vegetativa por enxertia com Araucaria angustifólia (Bert.) O. Ktze. IPEF. 1975;11:95-102.

Lima R, Inoue MT, Figueiredo Filho A, Araújo AJD, Machado SDA. Efeito do espaçamento no desenvolvimento volumétrico de Pinus taeda L. Floram. 2013;20(2):223-30.

Machado SDA, Zamin NT, Nascimento RGM, Santos AAPD. Efeito de variáveis climáticas no crescimento mensal de Pinus taeda e Araucaria angustifolia em fase juvenil. Floram. 2014;21(2):170-81.

Mattos PP, Braz E, Berndt E, de Oliveira YMM. Equação de volume para araucárias centenárias da Reserva Florestal Embrapa/Epagri. Colombo: 
Embrapa Florestas; 2010 (Comunicado técnico, 256).

Wendling I. Enxertia e florescimento precoce em Araucaria angustifolia. Colombo: Embrapa Florestas; 2011 (Comunicado técnico, 272).

Mencuccini M, Martínez-Vilalta J, Hamid HA, Korakaki E, Vanderklein D. Evidence for age and size mediated controls of tree growth from grafting studies. Tree Physiology. 2007;27:463-73.

Miguel EP, Canzi LF, Rufino RF, Santos GD. Ajuste de modelo volumétrico e desenvolvimento de fator de forma para plantios de Eucalyptus grandis localizados no município de Rio Verde GO. Enciclopédia Biosfera. 2010;6(11):1-13.

Moreira-Souza M, Cardoso EJBN. Dependência micorrízica de Araucaria angustifolia (Bert.) O. Ktze. sob doses de fósforo. Revista Brasileira de Ciências do Solo. 2002;26;905-12.

Nikles DG. Araucaria cunninghamii "bark-patch" grafting in the field. Australian Forest Research. 1961;1:45-7.

Pires PP, Wendling I, Brondani G. Ácido indol butírico e ortotropismo na miniestaquia de Araucaria angustifólia. Revista Árvore. 2013;37(3):393-9.

Puchalski A, Mantovani M, Reis MSD. Variação em populações naturais de Araucaria angustifolia (Bert.) O. Kuntze. associada a condições edafo-climáticas. Scientia Forestalis. 2006;70:137-48.

Reis CAF, Gonçalves FMA, Rosse LN, Costa RRGF, Ramalho MAP. Correspondence between performance of Eucalyptus spp. trees selected from family and clonal tests. Genetics and Molecular Biology. 2011;10(2):1172-9

Santin D, Wendling I, Benedetti EL, Morandi D, Domingos DM. Sobrevivência, crescimento e produtividade de plantas de erva-mate produzidas por miniestacas juvenis e por sementes. Ciência Florestal. 2015;25(3):571-9.

Schneider PR, Finger CAG, Hoppe JM. Produção da Araucaria angustifolia (Bert.) O. Ktze. na região da Planalto Médio do estado do Rio Grande do Sul. Ciência Florestal. 1992;2(1):99-118.

Schneider PR, Finger CAG, Klein JEM, Totti JA, Bazzo JL. Forma de tronco e sortimentos de madeira de Eucalyptus grandis para o estado do Rio Grande do Sul. Ciência Florestal. 1996;6(1):7988.

Shimizu JY, Higa AR. Variação racial do Pinus taeda L. no Sul do Brasil até o sexto ano de idade. Boletim de Pesquisas Florestais. 1981;2:125.

Xavier A, Wendling I, da Silva RL. Silvicultura clonal - Princípios e técnicas. $2^{\mathrm{a}}$. ed. Viçosa, MG: Universidade Federal de Viçosa; 2013. 280p.

Wendling I, Brondani G. Vegetative rescue and propagation of Araucaria angustifolia. Revista Árvore. 2015;39(1):93-104.

Wendling I, Dutra LF, Hoffmann HA, Bettio G, Hansel F. Indução de brotações epicórmicas ortotrópicas para a propagação vegetativa de árvores adultas de Araucaria angustifolia. Agronomia Costarricense. 2009;33(2):309-19.

Wendling I. Propagação vegetativa de erva-mate (Ilex paraguariensis Saint Hilaire): estado da arte e tendências futuras. Colombo: Embrapa Florestas; 2004 (Documentos, 91).

Wendling, I. Enxertia e florescimento precoce em Araucaria angustifolia. Colombo: Embrapa Florestas; 2011 (Comunicado técnico, 272).

Wendling I, Trueman SJ, Xavier A. Maturation and related aspects in clonal forestry-part II: reinvigoration, rejuvenation and juvenility maintenance. New Forests. 2014;45(4):473-86.

Wendling I. Tecnologia de enxertia de Araucaria angustifolia para produção precoce de pinhões. Colombo: Embrapa Florestas; 2015 (Comunicado técnico, 351).

Wendling I, Stuepp CA, Zuffellato-Ribas KC. Araucaria clonal forestry: types of cuttings and mother tree sex in field survival and growth. Cerne. 2016;22(1):19-26 
Zanette F, Oliveira LDS, Biasi LA. Grafting of Araucaria angustifolia through the four seasons of the year. Revista Brasileira de Fruticultura. 2009;19(4):425-31.

Zanon MLB, Finger CAG, Schneider PR.

Proporção da dióicia e distribuição diamétrica de árvores masculinas e femininas de Araucaria angustifolia (Bert.) Kuntze. em povoamentos implantados. Ciência Florestal. 2009;19(4):425-31.

Zhang K, Harry DE, Ma C, Yuceer C, Hsu CY, Vikram V, Strauss SH. Flowering newsletter Review Precocious flowering in trees: the flowering locus $\mathrm{T}$ gene as a research and breeding tool in Populus. Journal of Experimental Botany, 2010;61(10):2549-60. 